\title{
Plasmacytoid dendritic cell tumor: A case report
}

\author{
Plasmasitoid dendritik hücreli tumor: Bir olgu sunumu
}

\author{
Füruzan Kacar Döger ${ }^{1}$, Emel Dikicioğlu Çetin ${ }^{1}$, Mine Hekimgil2, \\ Meltem Özdoğan Uslu ${ }^{3}$, Gürhan Kadıköylü4, Nazan Özsan², Ekin Şavk³ ${ }^{3}$ Zahit Bolaman 4 \\ ${ }^{1}$ Department of Pathology, Faculty of Medicine, Adnan Menderes University, Aydın, Turkey \\ ${ }^{2}$ Department of Pathology, Faculty of Medicine, Ege University, Izmir, Turkey \\ ${ }^{3}$ Department of Dermatology, Faculty of Medicine, Adnan Menderes University, Aydin, Turkey \\ ${ }^{4}$ Deptartment of Hematology, Faculty of Medicine, Adnan Menderes University, Aydin, Turkey
}

\begin{abstract}
A 62-year-old man presented with a painless eruption on his arms and trunk. Physical examination showed 2 well-demarcated erythematous plaques on the anterior trunk and 6 purple-red papules on the back and upper extremities. Blood chemistry and computed tomography results were normal. Herein we describe a patient with plasmacytoid dendritic cell neoplasm in the absence of systemic symptoms. (Turk J Hematol 2011; 28: 312-6)

Key words: Cutaneous lymphoma, NK-cell lymphoma, hematodermic lymphoma, plasmacytoid dendritic cell neoplasm

Received: May 13, 2009

Accepted: April 30, 2010

Özet

Altmış iki yaşında erkek hasta gövdesinde ve kollarındaki ağrısız erupsiyon şikayetleri ile başvurdu. Fizik muyane de gövdesinin ön kısmında iyi sınırlı eritamatous plak, üst ekstremite ve sırtında mor kırmızı papuller saptand. Kan biyokimyası ve tomografisi olağandı. Burada, sistemik bulgusu olmayan plasmasitoid dendritik hücreli neoplasmı olan bir hastayı sunduk (Turk J Hematol 2011; 28: 312-6)

Anahtar kelimeler: Kutanöz lenfoma, NK hücreli lenfoma, hematodermik lenfoma, plasmasitoid dendritik hücreli neoplazi
\end{abstract}

Geliş tarihi: 13 Mayıs 2009

Kabul tarihi: 30 Nisan 2010

Address for Correspondence: Assoc. Prof. Füruzan Kacar Döger, Department of Pathology, Faculty of Medicine, Adnan Menderes University, 00910 Aydın, Turkey Phone: +90 5327958066 E-mail: fdoger@adu.edu.tr 


\section{Introduction}

According to the WHO 2008 classification of lymphoid malignancies, plasmacytoid dendritic cell tumor-a rare non-Hodgkin's lymphoma (NHL)-was formerly defined as blastic NK-cell lymphoma in the WHO 2001 classification and as CD4+/CD56+ hematodermic neoplasm in the European Organization of Research and Treatment of Cancer 2005 classification of cutaneous lymphoma [1-10]. Plasmacytoid dendritic cell tumors generally occur in middle-aged and elderly men; the skin is usually the first site of presentation in $90 \%$ of patients [1,4]. Additionally, there is a high incidence of lymph node and bone marrow involvement $[1,9,11,12]$. The tumor is characterized by a monotonous infiltrate of mediumsized cells with fine chromatin, resembling a lymphoblast. The overlying epidermis is not affected and there is a well-preserved grenz zone. Prognosis is poor and overall survival is $<2$ years [11-14].

\section{Case Report}

A 62-year-old male presented to Adnan Menderes University Hospital, Department of Dermatology with painless eruptions on his arms and trunk that began 5 months earlier (Figure 1). Physical examination showed 2 well-demarcated erythematous plaques $(4 \times 10 \mathrm{~cm}$ and $4 \times 5 \mathrm{~cm})$ on the anterior trunk of the body, and 6 purple-red papules (0.3-0.5$\mathrm{cm}$ ) on the back and upper extremities. Palpation of the liver and spleen was normal. The right axillary lymph node measured $4 \times 3 \mathrm{~cm}$. Written informed consent was obtained from the patient.

The patient's hematological parameters were as follows: Hb: $13.1 \mathrm{~g} / \mathrm{dL}$; Hct: 40\%; RBC count: $4.45 \times 10^{6}$ $\mathrm{mm}^{3}$; WBC count: $9.9 \times 10^{3} \mathrm{~mm}^{3}$; Plt count: $289 \times 10^{3}$ $\mathrm{mm}^{3}$. The erythrocyte sedimentation rate and C-reactive protein were $48 \mathrm{~mm} / \mathrm{h}$ and $11 \mathrm{mg} / \mathrm{L}$ (normal range: 0-6 mg/L), respectively. Peripheral blood smear, biochemical parameters, and bone marrow aspiration and biopsy were normal. Computed tomography of the cervix, thorax, abdomen, pelvis, and nasal cavity were normal, with the exception of the right axillary lymph node.

A punch biopsy was performed for definitive diagnosis. Histopathological examination of the biopsy specimen showed tumor infiltration in the dermis. The infiltrate was monotonous, involving the dermis and sometimes the subcutaneous tissue, and was composed of atypical medium-sized mononuclear cells with finely dispersed chromatin. The tumor consisted of medium-large blastoid-like cells. The epidermis was intact with a grenz zone (Figure 2). There are many mitotic figures. On the other hand, signs associated with a poor prognosis, such as necrosis and/or angioinvasion, were not observed; nor were inflammatory cells.

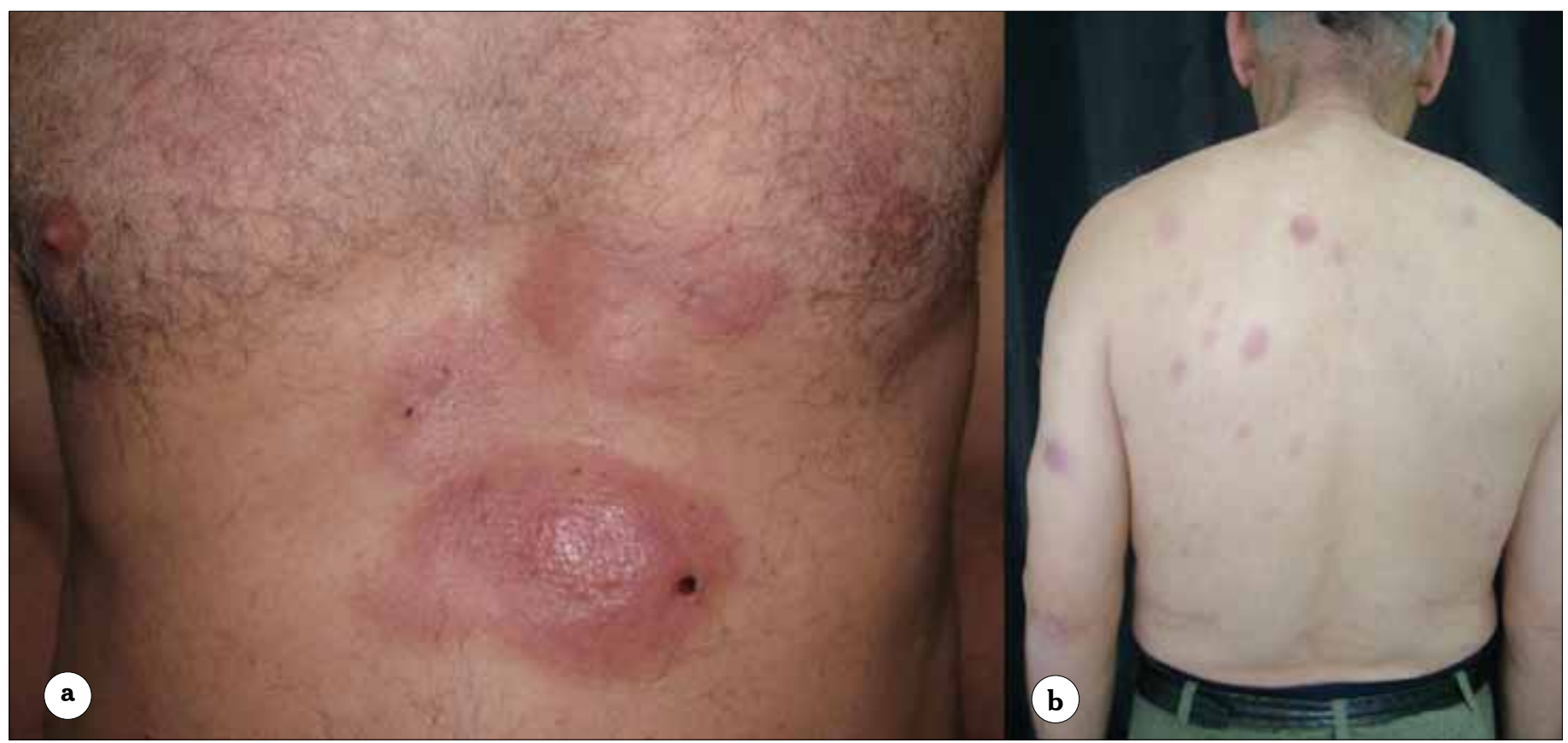

Figure 1a-b. Erythematous Nodules on the Patient's Chest (a) and Multiple Papules and Nodules on His Back and Arms (b) at Presentation 
The tumor cells stained positive for CD56 (Figure 3), CD4, and CD123, but did not stain with myeloperoxidase (MPO), TdT, CD34, CD20, CD3, CD5, CD 79, CD30, Cyclin D1, chromogranin, S100, or EBER. On the basis of the histopathologic findings, the patient was diagnosed as plasmacytoid dendritic cell neoplasm. The patient was stage IA-E, based on the Ann-Arbor staging system. CHOP (cyclophosphamide, adriamycin, vincristine, and prednisone) combination chemotherapy was administered as four 21-d courses [14]. After the first chemotherapy course the skin lesions regressed and lymphadenopathy disappeared (Figure $4 \mathrm{a}$ and b). During 2 years of follow-up skin lesions and bone marrow involvement did not recur.

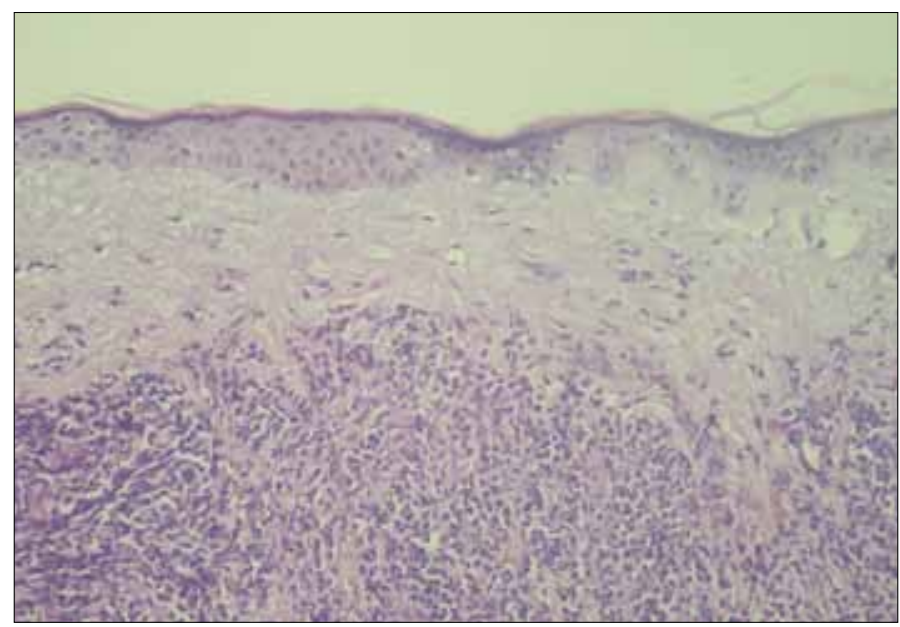

Figure 2. Intact Epidermis with A Grenz Zone (H\&E, 200×)

\section{Discussion}

Plasmacytoid dendritic cell tumors typical present with widespread purplish dermal nodules or tumors. These lesions are usually located on the trunk; however, the extremities, head, and neck can be involved. Most patients also have extracutaneous manifestations at presentation $[1,4,5,10]$. Plasmacytoid dendritic cell tumors were formerly categorized as blastic NK-cell lymphoma because of CD56 expression [1-3,6,7,11,13]. Moreover, CD4 expression is positive, but CD2, CD3, and CD7 expression is usually negative. While CD68 is negative or slightly positive, TdT and CD34 may be positive in some cases, but evidence of T-cell receptor (TCR) gene rearrangement

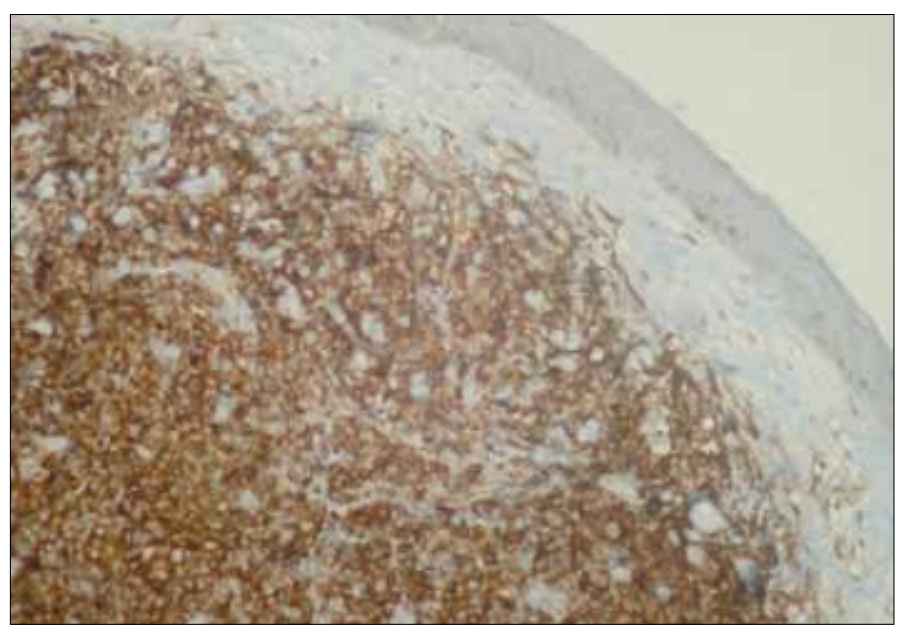

Figure 3. Tumor Cells with Strong Positive CD56 Staining (CD56, 200×)

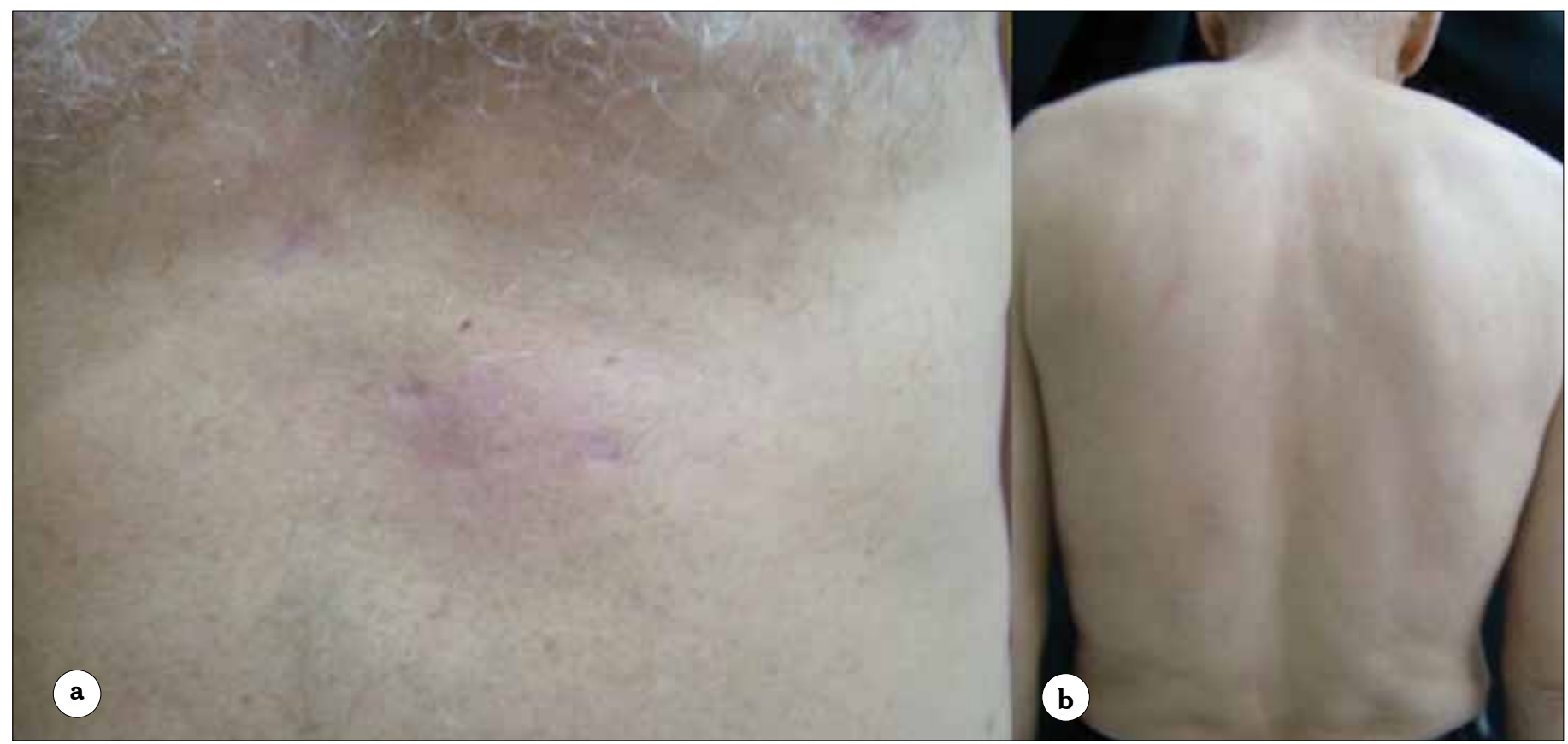

Figure 4 a-b. Regression of the Patient's Lesions Following Chemotherapy 
is absent $[4,13]$. While there is no tumor formation in the nasal cavity, skin tumors accompanied by enlargement of lymph nodes are frequently observed. No correlation with the Epstein-Barr virus has been reported.

Between 1994 and 2007 there were 121 reported cases of plasmacytoid dendritic cell neoplasm). The presented patient had painless cutaneous eruptions and lymphadenopathy. Skin biopsy of these lesions showed neoplastic infiltration of the dermis with a grenz zone. Additionally, there was a high mitotic rate. Neoplastic cells were atypical and had a blastic appearance. Histologically, the lymphomas showed no significant epidermotropism. Immunohistochemical staining was very typical for plasmacytoid dendritic cell neoplasm. Although the blastic cytological appearance and CD56 expression initially suggested that NK-cells were the origin of this type of lymphoma, more recent studies reported that the cells express CD123 and TCL1, suggesting a plasmacytoid dendritic cell origin [2,6,7,9-11].

Currently, although no characteristic cutaneous manifestations are known and no consensus on the treatment of plasmacytoid dendritic cell tumors exists, aggressive chemotherapy regimens are recommended. Anthracycline-based chemotherapies, such as the CHOP and hyper-CVAD regimens, may be effective, whereas high-dose chemotherapy and autologous stem cell transplantation may be appropriate in some selected cases $[3,5,8-11,13]$. The presented patient received the $\mathrm{CHOP}$ chemotherapy regimen, and after the first course the patient's skin lesions regressed and lymphadenopathy disappeared. During 2 years of follow- skin lesions and bone marrow involvement did not recur.

In conclusion, plasmacytoid dendritic cell tumors are a rare form of cutaneous malignant lymphoma. This neoplasm has an aggressive course and rapid development of disseminated disease in the majority of patients. Definitive pathological diagnosis is essential for proper treatment and a good prognosis. Future research should focus on the characterization of this lymphoma and the establishment of effective treatment modalities.

\section{Conflict of interest statement}

The authors of this paper have no conflicts of interest, including specific financial interests, rela- tionships, and/or affiliations relevant to the subject matter or materials included.

\section{References}

1. Chan JKC, Jaffe ES, Ralfikiaer E. Blastic NK-cell lymphoma. In: Jaffe ES, Harris N, Stein H, et al, editors. Pathology and genetics of tumors of hematopoietic and lymphoid tissues. Lyon, France: IARC Press 2001;214-5.

2. Slater N. The new World Health Organization-European Organization for Research and Treatment of Cancer classification for cutaneous lymphomas: a practical marriage of two giants. Br J Dermatol 2005;153:874-80. [CrossRef]

3. Leitenberger JJ, Berthelot $\mathrm{CN}$, Polder KD, Pro B, McLaughlin P, Jones D, Duvic M. J CD4+ CD56+ hematodermic/plasmacytoid dendritic cell tumor with response to pralatrexate. J Am Acad Dermatol 2008;58:480-4. [CrossRef]

4. Akasaka E, Mabuchi T, Umezawa Y, Iwashita K, Ohta Y, Matsuyama T, Ozawa A. A case of blastic NK-cell lymphoma. Int J Dermatol 2007;46:722-6. [CrossRef]

5. Bayerl MG, Rakozy CK, Mohamed AN, Vo TD, Long M, Eilender D, Palutke M. Blastic natural killer cell lymphoma/leukemia: a report of seven cases. Am J Clin Pathol 2002;117:41-50.

6. Herling M, Jones D. CD4+ CD56+ hematodermic tumor: the features of an evolving entity and its relationship to dendritic cells. Am J Clin Pathol 2007;127:687-700. [CrossRef]

7. Garnache-Ottou F, Feuillard J, Sass P. Plasmacytoid dendritic cell leukemia/lymphoma: towards a well defined entity? Br J Haematol 2007;136:539-48. [CrossRef]

8. Petrella T, Bagot M, Willemze R, Beylot-Barry M, Vergier B, Delaunay M, Meijer CJ, Courville P, Joly P, Grange F, De Muret A, Machet L, Dompmartin A, Bosq J, Durlach A, Bernard P, Dalac S, Dechelotte P, D'Incan M, Wechsler J, Teitell MA. Blastic NK-cell lymphomas (agranular CD4+CD56+ hematodermic neoplasms): a review. Am J Clin Pathol 2005;123:662-75. [CrossRef]

9. Khoury JD, Medeiros LJ, Manning JT, Sulak LE, BuesoRamos C, Jones D. CD56(+) TdT(+) blastic natural killer cell tumor of the skin: a primitive systemic malignancy related to myelomonocytic leukemia. Cancer 2002;94:2401-8. [CrossRef]

10. Ng AP, Lade S, Rutherford T, McCormack C, Prince HM, Westerman DA. Primary cutaneous CD4+/CD56+ hematodermic neoplasm (blastic NK-cell lymphoma): a report of five cases. Hametologica 2006;91:143-4.

11. Niakosari F, Sur M. Agranular CD4+/CD56+ hematodermic neoplasm: a distinct entity described in the recent World Health Organization-European Organization for Research and Treatment of Cancer classification for cutaneous lymphomas. Arch Pathol Lab Med 2007;131:149-51.

12. Suzuki R, Nakamura S, Suzumiya J, Ichimura K, Ichikawa M, Ogata K, Kura Y, Aikawa K, Teshima H, 
Sako M, Kojima H, Nishio M, Yoshino T, Sugimori H, Kawa K, Oshimi K; NK-cell Tumor Study Group. Blastic natural killer cell lymphoma/leukemia (CD56-positive blastic tumor): prognostication and categorization according to anatomic sites of involvement. Cancer 2005;1:1022-31. [CrossRef]

13. Ascani S, Massone C, Ferrara G, Rongioletti F, Papini M, Pileri S, Cerroni L. CD4- negative variant of CD4+/CD56+ hematodermic neoplasm; description of three cases. J Cutan Pathol 2008;35:911-5. [CrossRef]

14. Yamada O, Ichikawa M, Okamoto T, Park C, Motoji T, Mizoguchi H, Shibuya A. Killer T-cell induction in patients with blastic natural killer cell lymphoma/leukaemia: implications for successful treatment and possible therapeutic strategies. Br J Haematol 2001;113:153-60. [CrossRef] 